\title{
Irish GP referral rates and influencing factors
}

\author{
P Gouda1*, C Mahambo' ${ }^{1}$ C Eamonn², L Glynn', G Glynn \\ From International Conference for Healthcare and Medical Students (ICHAMS) 2013 \\ Dublin, Ireland. 11-12 October 2013
}

\section{Background}

General practitioners (GPs) play a key role as the gatekeepers of access to secondary care in Ireland, and indeed in many healthcare systems worldwide [1]. This role has been shown to be crucial in providing cost-effective healthcare delivery. Our study aimed to analyse the GP referral process and the factors by which referral rates may be influenced, particularly those that are unique to the Irish healthcare system.

\section{Methods}

Eighty GPs of the County Sligo General Practitioners' Society participated between July 2011 and November 2011. For 100 consecutive patient consultation each GP record: patient age, gender, GMS status, and whether or not the patient was referred. In the case of a referral, the GP was asked to specify to what specialty they were referred. Statistical analysis was conducted using PASW Statistics 20.0.

\section{Results}

Of the 7993 consultations, 936 (11.7\%) patients were referred to secondary care. There was a wide spectrum of GP referral rates, ranging from $1 \%$ to $26 \%$, with a mean average GP referral rate of $11.7 \%+/-.72 \%$. The emergency department received the greatest proportion of GP referrals (25\%). GMS eligibility was found to be associated with referral rates, with $9.7 \%$ of GMS eligible patients referred to secondary care compare to $15.3 \%$ of GMS ineligible patients, OR 1.67 (95\% CI 1.45-1.92). GP gender was also associated with referral rates, with female GPs having a referral rate of $13.2 \%+/-6.1$ compared to male GPs at $10.4 \%+/-6.5(\mathrm{p}=0.016)$.

\section{Conclusions}

Our study demonstrates a wide range of GP referral rates. Rather than attempting to standardise referral

${ }^{1}$ National University of Ireland, Galway, Ireland

Full list of author information is available at the end of the article rates, studies suggest we should strive to reduce inappropriate referral rates [2]. As a result, future studies should aim to measure both the appropriateness of referrals as well as the outcomes of the referral. Although studies of this sort have been conducted in the UK, they have yet to be reproduced in Ireland.

\section{Authors' details}

${ }^{1}$ National University of Ireland, Galway, Ireland. ${ }^{2}$ Ark Medical Centre, Unit 1B, Letterkenny Town Centre, Pearce Road, Letterkenny, Co Donegal, Ireland.

Published: 14 January 2015

\section{References}

1. Brekke KR, Nuscheler R, Straume OR: Gatekeeping in health care. J Health Econ 2007, 26(1):149-70.

2. O'Donnell CA: Variation in GP referral rates: what can we learn from the literature? Fam Pract 2000, 17(6):462-71.

doi:10.1186/1753-6561-9-S1-A14

Cite this article as: Gouda et al:: Irish GP referral rates and influencing factors. BMC Proceedings 2015 9(Suppl 1):A14.
Submit your next manuscript to BioMed Central and take full advantage of:

- Convenient online submission

- Thorough peer review

- No space constraints or color figure charges

- Immediate publication on acceptance

- Inclusion in PubMed, CAS, Scopus and Google Scholar

- Research which is freely available for redistribution
() Biomed Central 